\title{
Boardroom or War Room: An Expectational Analysis of CFO - Executive Board Relationships in Adventist Local Conferences
}

\author{
Theodore Brown Sr., Ph.D. \\ Professor of Management and Leadership, Oakwood University \\ Department of Business and Information Systems \\ School of Business, 7000 Adventist Boulevard NW \\ Huntsville, Alabama
}

\begin{abstract}
The Board of Directors represents the highest level of organizational governance. The basis of this paper was instigated by the thought that the perceptions of SDA Local Conference leadership consequentially impact how the relationships of CFOs and their Executive Boards are viewed based upon perceived expectations. Data was collected from a purposeful sample of $\mathrm{N}=399$ at fifty-seven SDA Local Conference in the NAD. Response rate was 55\%. A Mixed-Methods sequential exploratory research design was used.
\end{abstract}

Keywords: Board Governance, CEO (Chief Executive Officer/President), CFO (Chief Financial Officer/Treasurer), Executive Board Members, General Conference (GC), leadership, North American Division (NAD), perceptions, CFO-CEO relationships, Sarbanes-Oxley Act (SARBOX), Seventh-day Adventists (SDA)

\section{INTRODUCTION}

\section{CFO-Executive Board Relationships in SDA Context:}

The Seventh-day Adventist (SDA) Church, as world-wide organization, has continued to experience exponential financial growth and expansion (Adventist World - NAD 2013, p. 5). This continual organizational proliferation has dramatically influenced and re-shaped how conferences are governed; specifically the Chief Financial Officers (CFOs/Treasurers) and Executive Board relationships. While the North American Division (NAD) Working Policy (2015-2016) and the SDA Accounting Manual (2011) accentuate the expected functional and governance relationships of conference CFOs (Treasurers) and Executive Boards with each other; uncertainty may still tend to exist pertaining to the amplitude of their relationships, and its sway in terms of outcomes in areas of organizational efficiency, effectiveness and productivity.

As with any business or organization entity (for profit and not-for profit); SDA local conferences are not immune from the effects and influences of changes in governmental legislations occurring in domestic and global environments and societies. Therefore, complimentary and favorable $\mathrm{CFO}$ and Executive Board relationships expectations (Buckingham and Coffman, 1999) must be clearly defined, encouraged, established, nurtured and sustained; especially in SDA local conferences to realize its objectives and purpose (mission).

\section{LITERATURE}

\section{The Emerging Role and Responsibilities of the CFO}

The evolution of the CFO's role has continued to expand significantly in scope and responsibility primarily in response to the result of the increasing complexity in government(s) requirements and regulation(s) in addition to pressures in corporate industry 
competition in global business environments, markets and societies to secure and sustain marketability and profitability for their organizations (Karabus, 2017; Kulshrestha, 2017). According to Ode (2016), the CFO, in most organizational sectors, is considered as the second in command to the CEO (Whiteman, 2015). During the 1990's, the CFO role begin shifting from more of traditional and functional accounting, reporting and financial management duties to engaging in greater duties such a being a strategic partner and corporate leader with more emphasis shaping strategy and driving innovation, strategic thinking, ensuring regulatory compliance, managing risk and looking to create and increase organizational and shareholder's value (Littlewood, 2017; Vollmer, 2017; Williams, 2012; Steinhoff and Price, 2011; Corporate Finance, 2005).

In the future, expectations of CFOs will continue to change as new challenges occur as societal influences impact how business operate. Uncertain and unforeseen internal and external environmental domestic and global forces on organizations will require CFOs to authentically and openly communicate wider transparently and demonstrate more leadership effectiveness while focusing more on medium and long-term growth aspects in their industries without negating the importance of short-term challenges such as company's cyber-security, new business models, profitability, meeting operational goals and objectives, and technology innovations (Holley, 2017; Vercic and Zerfass, 2016; Westfall, 2015, Dotlich, 2006).

\section{The Role and Function of the Executive Board}

According to Holley (2018) "the role of boards and the issues they oversee have expanded amid the accelerated rate of change, disruption and transformation that defines today's business environment". The purpose of the board and board service in corporate America has also evolved over twenty years ago from a perceived position of cushiness, "morning presentations by management", "liquid lunch", "cigars" and "a place for glory where people were recognized"; to being held to highest level of commitment and service to governance in addition to having a broader understanding of business, economic, governmental industry issues impacting the organization such as creating and increasing company marketability and sustainability, crisis management, compliance (SARBOX), maximizing shareholder and stakeholder value and wealth, profitability, addressing risk and regulatory challenges, investing in social responsibility and strategic oversite (Merker, 2018; Raymond, 2018; Banerjee and Kaya, 2017; Madhani, 2017; Talaulicar, Judge and Mallon, 2017; Venkatraman, 2015; Colvin, 2013).

The success of executive boards in fulfilling its functional role and responsibilities as the center and foundation of an entities' governance significantly impacts the financial outcomes and overall operating performance, effectiveness and efficiency of the corporation and organization (Malik and Makhdoom, 2016). Gwin, Lesueur and Sanders (2018) noted the complexity of today's business climate and culture requires boards to accelerate their functional strategy capacity) into areas such as (1) Working Board (Portfolio Investor Strategy); (2) Thinking Board (Customer Intimate Strategy); (3) Responsive Board (Execution Engine Strategy); and (4) Inspiring Board (Talent Magnet Strategy) to develop specific approaches to be proactive in the oversite of establishing and monitoring the strategy initiatives of the business they serve to ensure that the well-being of the shareholders and stakeholders are maximized (Moran, 2016). It is also essential and vital to a company's competitive advantage, marketability, operating performance and sustainability that boards' composition be representative of the stakeholders, communities and consumers that the company serves, and include people with diverse backgrounds, orientations, abilities and professions to attract future investors and customers (Toumi, Benkraiem and Hamrouni, 2016; Bhuiyan, 2015; Boerner, 2015; Swedberg, 2015; Dingle, 2014). 


\section{The Impact of Sarbanes-0xley Act (SARBOX) on CFO-Board Relationships}

According to McCann (2017) the Sarbanes-Oxley Act of 2002 was primarily incorporated to address and institute mechanisms for controlling financial scandals in business and corporations. Heffes (2007) stated a significant part of the CFO's job is to communicate with the executive board of directors, and the Sarbanes-Oxley Act of 2002 made the CFO's reporting to the executive board even more critical to the corporation. In addition to the CFO's accountability and reporting to the executive board, the passing of Sarbanes-Oxley was also enacted to minimize business and corporate fraud, improve financial reporting quality, enhance board accountability, governance and independence, create and ensure compliance officer independence, cultivate maintenance of $\mathrm{CFO}$ and board relationships and protect company assets (Holly, 2018; Snell, R. 2017; Franklin, 2016; Aquilio, 2016; Joseph, 2015; Krishnan, Gopal, Raman, Yang and Yu, 2011).

However, adaptation and implementation of the legislature of Sarbanes-Oxley has not been an easy transition for some board of directors due to the necessity of being influenced and undermined by social ties with the CEO and/or CFO; board members requiring a deeper knowledge and understanding of the business operations and processes above just getting the financial reports due to excessive information; and it has also created numerous challenges for businesses to meet compliance (Linden, 2012; Krishnan, Raman, Yang, and Yu, 2011; Krell, 2006; Krell, 2005).

\section{METHODOLOGY}

A mixed methods research design (Creswell, 2014) was used in this study. Creswell (2003) "defines mixed methods research by incorporating the definition that focuses on collecting and analyzing both quantitative and qualitative data in a single study" (p. 210). A sequential exploratory design involving qualitative (Eriksson and Kovalainen, 2008; Nardi, 2003) and quantitative (Elsbach and Bechky, 2009) methods was utilized first in interviewing presidents and treasurers from four exemplary SDA Local conferences, and then secondly the collection and analysis of the survey data collected from a purposeful sample of $\mathrm{N}=399$ at fifty-seven SDA Local conference throughout North America (Bermuda, Canada and USA). A 55\% response rate was realized. The primary focus of this paper is quantitative pertaining to the study topic. ANOVAs, Likert Scale and Student-Newman-Keuls Post-Hoc Test were the primary statistical analysis used for each of the survey questions pertaining to the treasurer's relationship to the Executive Board.

\section{RESULTS}

Research Question 1b: Is there congruence between the perceptions of the presidents, treasurers and executive board members as they relate to the way the roles, responsibilities and relationships of the treasurers have changed?

\section{Quantitative Findings}

The results summary of question $1 \mathrm{~b}$ pertaining to the treasurer's relationship to the Executive Board is presented with the means for the individual groups (presidents, treasurers, and board members). It should be noted that the Likert Scale used ranged from 1 (strongly disagree) through 5 (strongly agree). The higher the mean score, the more respondents agree with the survey questions. 
Individual Group Means for the Treasurer's Relationship to the Executive Board

Questions of Treasurer's Relationship to the
\begin{tabular}{|l|l|l|l|l|} 
Executive Board & Presidents & Treasurers & Board Members \\
\hline 30 & $\begin{array}{l}\text { Relationship of treasurer changed from past, } \\
\text { present, future. }\end{array}$ & 3.23 & 3.53 & $3.63^{*}$ \\
\hline 31 & $\begin{array}{l}\text { Relationship is enhanced by providing accurate } \\
\text { reports. }\end{array}$ & 4.49 & 4.62 & 4.61 \\
\hline 32 & $\begin{array}{l}\text { Credibility is built by presenting simplified } \\
\text { reports. }\end{array}$ & 4.63 & 4.67 & 4.58 \\
\hline 33 & $\begin{array}{l}\text { Failure to follow board directives can create } \\
\text { adversity. }\end{array}$ & $4.43^{*}$ & 4.05 & $4.34^{*}$ \\
\hline
\end{tabular}

*Denotes pairs of groups significantly different at the .05 level.

Pertaining to Question 30; the relationship of the treasurer to the board has changed over the years and will continue to evolve in the future (The total group mean of 3.54 indicates that the three groups tended to agree with this statement).

Pertaining to Questions 31; the treasurer's relationship with the board is enhanced by providing accurate and timely financial statements (The total group mean of 4.59 indicates that the three groups tended to strongly agree with this statement).

Pertaining to Question 32; a treasurer builds credibility with the board by presenting simplified financial reports with full disclosure (The total group mean of 4.60 indicates that the three groups tended to strongly agree with this statement).

Pertaining to Question 33; failure to carry out the board's directives in a timely manner can create an adverse relationship between a treasurer and the board (The total group mean of 4.30 indicates that the three groups tended to agree with this statement).

\section{Qualitative Findings}

\section{A Researcher's Observation on CFO/Executive Board Relationships in SDA Boardrooms:}

According to Brown (2005, pg. 102-103) "As the researcher, I was able to observe and record detailed notes (Appendix $G$ ) of the executive board meetings of each exemplary conference where the treasurer was responsible for presenting financial reports to the board. The treasurers' relationships with their executive boards during the meetings I observed were pleasant and responsive. A bond between the two groups was visible.

It became quite evident that the treasurers were very competent and skilled in financial leadership and management. They all did an outstanding job of presenting the financial reports, supporting their presidents, and contributing to the non-financial agenda items of their conference. In each case, after the treasurer presented his or her report, the president and members of the board expressed their appreciation to the treasurer and the treasury department for the outstanding work they were doing as reflected in the treasurer's report. There was a great deal of positive humor and verbal exchange between the treasurer, president and board members in each conference which resembled a partnership between the three sectors of the conference leadership team. The board members listened intently to the reports and asked questions, made comments, and eventually voted to accept the treasurer's reports". 


\section{IMPLICATIONS AND CONCLUSIONS}

In summary, the results of the questions pertaining to the expectations of the treasurer's relationship to the executive board indicate and support that the treasurers and executive boards are experiencing changing relationships, and that the treasurer's relationship with the executive board is enhanced by the degree in which the treasurer reports to the board and responds to board directives. The executive board is the governing body of an organization, and the CFO is ultimately accountable to the executive board as it pertains to the positon's role and functioning responsibilities. Essential to establishing and maintaining CFO efficiency and productivity is having effective and feasible working relationships that fulfill the governmental legislative requirements of the Sarbanes-Oxley Act (SARBOX) where applicable. Therefore, the effective communication and understanding of corporate leadership expectations are foundational in the maximization of the CFO and executive board relationships especially in fostering and facilitating the well-being of all its stakeholder and subsidiaries. The selection of the "right" fit CFO and the "right" fit individuals to serve on the executive board is necessary to achieving positive results in the boardroom atmosphere. Whereas poor selections in any of the areas mentioned above may create a war room atmosphere, and equipoise the advancement of an effective and efficient operating environment that fulfills and represents in a measurable manner the organization's mission of climate and culture.

\section{References}

Adventist World - NAD (2013, June). Treasurer says north american tithe up 1 percent, 4.4 percent in other regions. p. 5.

Aquillio, M. (2016, February). Sarbanes-Oxley and the fishing expedition. ASBBS Proceedings. 23.1: 31-40. San Diego: San Diego American Society of Business and Behavioral Sciences.

Banerjee, G. and Kaya, H. D. (2017). Short-term and long-term impact of sarbanes-oxley act on director commitment and composition of corporate board committees. Journal of Financial Management and Analysis. 30(1): 2017: 1-11.

Bhuiyan, Md. B.U. (2015). Do problems directors affect firm operating performance? Asian Review of Accounting. 23.2: 170-185.

Boerner, H. (2015, March/April). Importance of intangibles reflected in esg performance metrics for a growing number of investors. Corporate Finance Review. 19.5: 28-32.

Brown, T. (2005). A study of the expectations of treasurers as chief financial officers in local conferences in the north American division of seventh-day Adventist: Perceptions of roles, responsibilities and relationships. Andrews University. Berrien Springs, MI. Dissertation. Pg. 102-103.

Buckingham, M. and Coffman, C. (1999). First break all the rules: What the world's greatest managers do differently. New York: Simon \& Schuster.

Colvin, G. (2013, May). Inside the boardroom: The party is over! Fortune. 219-224.

Corporate Finance (2005, April). Cfo to ceo. Corporate Finance. 1.

Creswell, J. (2003). Research design: Qualitative, quantitative, and mixed methods approaches (2 ${ }^{\text {nd }}$ ed.). Thousand Oaks, CA: Sage. p. 210.

Creswell, J. (2014). Research design: Qualitative, quantitative, and mixed methods approaches (4th ed.). Thousand Oaks, CA: Sage.

Dingle, D. T. (2014, July/August). Where are the blacks in corporate boardrooms? Black Enterprise. 66-90.

Dotlich, D.L. (2006). Developing cfos as whole leaders. Financial Executive. 22.6.

Elsbach, K.D. and Bechky, B.A. (2009). Qualitative Organizational Research (Vol. 2). Charlotte, NC. Information Age Publishing, Inc.

Eriksson P. and Kovalainen, A. (2008). Qualitative Methods in Business Research. Thousand Oaks, CA: Sage.

Franklin, M. (2016, July). Sarbanes-Oxley section 404: A historical analysis. Journal of Accounting and Finance. 16.4: 56-59. 
Gwin, B.W.; Lesueur, A. and Sanders, J. (2018). Four approaches of 'superaccelerator' boards: Fast-growing companies provide governance formulas for accelerating value. Directors \& Boards Winter 2017: 52+. Business Insights: Essentials. Web. 11 Jan. 2018.

Heffes, E.M. (2007, October). Audit committee to cfo: Can we talk? Financial Executive. 23.8: 28-32.

Holley, C. (2018 January). Essentials for the board-cfo relationship: Here is a set of questions boards can use to explore and define the attributes they might want from a cfo. Directors \& Boards 2017 First Quarter, Vol. 41 Issue 2. P16-17. 2p.

Joseph, S.M. (2015, March). Board independence, corporate governance, and fraud: A review of the empirical research and direction for the future. Oil, Gas \& Quarterly. 63.3:433.

Karabus, A. (2017, March/April). Cfo evolution. Chain Store Age. Vol. 93 Issue 2, p26-26. 1/4p.

Krell, E. (2005, May). Sarbanes fatigue strikes the boardroom. Business Finance. 11.5: 45-48.

Krell, E. (2006, August). Tuning up the cfo-board relationship. Business Finance. 12.8: 17.

Krishnan, G., Ramam, K.K., Yang, K., and Yu, W. (2011, September). Cfo/ceo - board social ties, sarbanes-oaley, and earnings management. Accounting Horizons. 25.3:537-557.

Kulshrestha, T. (2017, September). Corporate finance: The new cfo. Global Finance. 30-31.

Linden, M. (2012, October). The modern-day cfo: Down to business. Financial Executive. 28.8: 49-51.

Littlewood, S. (2017, January). Boxed out of strategic thinking? Global Finance. Vol. 31 Issue 1, p52-53. 2p.

Madhani, P. M. (2017). Diverse roles of corporate board: A review of various corporate governance theories. IUP Journal of Corporate Governance. Vol. 16 Issue 2. P7-28. 22p.

Malik, M.S. and Makhdoom, D.D. (2016). Does corporate governance beget firm performance in fortune global 500 companies? Corporate Governance. 16.6:747-764.

McCann, D. (2017, October). Research refutes sarbanes-oxley critics: Strong evidence exist of a link between auditor-identified weak internal controls and subsequent fraud cases. CFO. Vol. 33 Issue 8, p10-11. 2p.

Merker, C. K. (2018, January). Governance matters: Pension plan board effectiveness. Benefits Magazine. 28-33.

Moran, J. (2016, June). Bringing board performance into focus. Accountancy Ireland. 48.3: 64-65.

Nardi, P.M. (2003). Doing Survey Research: A Guide to Quantitative Methods. Boston, MA. Allyn and Bacon.

North American Division Working Policy (2015-2016). North American Division of the General Conference; Silver Springs, MD.

Ode, F. (2016, May/June). Who's leading your company? Look for the chief problem officer. Construction Accounting \& Taxation. 26.3:6-10.

Raymond, D. (2018, January). Measuring impact in the boardroom: B corps setting the standard for measuring sri. Directors \& Boards Winter 2017: 33+. Business Insights: Essentials. Web. 10 Jan. 2018.

Seventh-day Adventist Accounting Manual, (2011 Edition/January). General Conference of Seventh-day Adventists. Silver Spring, Maryland. p. 4 -7.

Snell, R. (2017, May/June). Compliance officer independence is still an issue after roughly 22 years: Conflicted reporting relationships continue to exist in compliance. Journal of Health Care Compliance. Vol. 19 Issue 3, p3-4. 2p. 1Black and White Photograph.

Steinhoff, J.C. and Price, L.A. (2011, Spring). From back room to board room: Federal cfo role in managing the cost of government. Public Manager. 40.1: 56-61.

Swedberg, J. (2015, October). Making it work. Credit Union Management. 38.10: 40-42.

Talaulicar, T.; Judge, W.Q. and Mallon, M. (2017). What drives prescriptions of board involvement in corporate governance codes? Academy of Management Annual Meeting Proceedings. Vol. 2017 Issue 1, p1-1. 1p.

Toumi, N; Benkraiem, R and Hamrouni, A. (2016). Board director disciplinary and cognitive influence on corporate value creation. Corporate Governance. 16.3: 564-578.

Venkatraman, S. (2015, February). Business partnering: When does it work? Strategic Finance. 96.8: 47-48, 5153.

Vercic, D. and Zerfass, A. (2016). A comparative excellence framework for communication management. Journal 
Brown, T. (2018). Boardroom or War Room: An Expectational Analysis of CFO - Executive Board Relationships in Adventist Local Conferences. Archives of Business Research, 6(4), 84-90.

of Communication Management; London. 20.4: 270-288.

Vollmer, S. (2017, April). How a cfo can become great. Journal of Accountancy: Management Accounting. 36-39.

Westfall, C. (2015). Cfo of the future: Strategy \& substance. Financial Executive. 31.3: 50-56.

Whiteman, R. (2015, September). Necessary medicine. Public Finance. 9:17.

Williams, J. (2012, January). From cfo to ceo transitioning to the top spot. Healthcare Financial Management. 66.1: 58-63. 